Diabetologia 4, 268-272 (1968)

\title{
Histological and Histochemical Changes in the Coronary Arteries of Old Diabetic Patients*
}

\author{
Thomas Leder
}

The University Institute of Pathology (Head: Professor STEEN OLSEN) and the 2nd University Clinic of Internal Medicine (Head: Professor KNun LundBaki). Kommunehospitalet, Aarhus, Denmark

Received: October 26, 1967

Summary. In a study of the coronary arteries from 20 old diabetics and 20 old patients without clinical diabetes the following findings were obtained: -1 . The distal part of the extramural coronary artery from the diabetic patients contained more hyaline, PAS-positive material and fat in the intima than did that of the nondiabetic patients, but did not show a higher degree of metachromasia. - 2. There was more calcium in the proximal as well as in the distal part of the extramural coronary arteries in the diabetics than in the non-diabetics. - 3. Severe PAS-positive deposits were found in the smallest intramural branches much more often in diabetics than in non-diabetics. - 4. The PAS-positive substance did not react to staining for acid mucopolysaccharides, glycogen, collagen, fibrin or reticulin. - 5 . Endothelial proliferation was not observed in the small vessels with PAS-positive material. - 6. There was no measurable difference in the wall thickness of the smallest intramural vessels between the diabetic and non-diabetic patients. - 7. The incidence of PAS-positive small vessels of the myocardium was closely related to the incidence of nodular glomerulosclerosis in the kidney. There was no such relation to the blood pressure.

Modifications histologiques et histochimiques dans les artères coronaires de patients diabétiques âgés

Résumé. Au cours d'une étude des artères coronairos de 20 diabétiques âgés et de 20 patients âgés sans diabète clinique, on a obtenu les résultats suivants: - 1. La partie distale de l'artère coronaire extramurale des patients diabétiques contenait plus de substance hyaline, de substance PAS-positive et de graisse dans l'intima que celle des patients non-diabétiques mais ne présentais pas un plus haut degré de métachromasie. -2 . Il y avait plus de calcium aussi bien dans la partio proximale que distale des artères coronaires extramurales chez les diabétiques que chez les non-diabétiques. - 3. D'importants dépôts PAS-positifs ont été trouvés dans les plus petites branches intramurales bien plus souvent chez les diabétiques que chez les nondiabétiques. - 4. La substance PAS-positive ne réagissait pas à la coloration des mucopolysaccharides acides, du

Numerous elinical and autopsy studies have demonstrated that the incidence of coronary artery disease is higher in diabetics than in non-diabetics (CLAwSON and BeLL, 1949; LUNDBesk, 1953; LImBOw etal., 1955; Nielsen, 1967).

Macroscopically the appearance of the extramural coronary artery lesions in diabetics and non-diabetics is the same, and early histological studies failed to reveal any significant differences (Root, 1928). It was concluded, therefore, that the high incidence of coro-

* The present study was part of a prize paper submitted to the University of Aarhus in 1965 . glycogène, du collagène, de la fibrine ou de la réticuline. 5. On n'a pas observé de prolifération endothéliale dans les petits vaisseaux qui contenaient la substance PASpositive. - 6. Il n'y avait pas de différences mesurables dans l'épaisseur de la paroi des plus petits vaisseaux intramuraux des diabétiques et des non-diabétiques. - 7. La présence des petits vaisseaux PAS-positifs du myocarde était en relation étroite avec la présence de glomérulosclérose nodulaire dans le rein. Il n'y avait pas de relation avec la pression sanguine.

Histologische und histochemische Veränderungen in den Coronarien von Altersdiabetikern

Zusammenfassung. Eine Untersuchung der Coronararterien von 20 Altersdiabetikern und 20 älteren Personen ohne klinischen Diabetes führte zu folgenden Befunden: - 1. Der distale Anteil von extramuralen Coronarien von Diabetikern enthielt mehr hyalines, PAS-positives Material und Fett in der Intima als die Gefäße von Nichtdiabetikern, zeigte aber keine stärkere Metachromasie. 2. Bei Diabetikern fand sich in den proximalen und distalen Abschnitten der extramuralen Coronarien mehr Calcium als bei Nichtdiabetikern. - 3. In den kleinsten intramuralen Verzweigungen ließen sich bei Diabetikern wesentlich häufiger als bei Nichdiabetikern schwere, PAS positive Ablagerungen nachweisen. - 4. Dieses PAS positive Material ließ sich nicht auf Mucopolysaccharide, Glykogen, Kollagen, Fibrin oder Reticulin anfärben. 5. Kleine Gefäße mit PAS positiven Ablagerungen wiesen keine Endothel-Proliferation auf. - 6. Kleinste intramurale Gefäße von Diabetikern und Nichtdiabetikern zeigten keine Unterschiede in der Wandstärke. - 7. Es fand sich eine enge Korrelation zwischen der Häufigkeit PAS-positiver Arteriolen und dem Auftreten nodulärer Glomerulosklerose in den Nieren. Zur Höhe des Blutdruckes ließen sich derartige Beziehungen nicht nachweisen.

Key-words: Heart, coronary arteries, diabetes mellitus, long-term diabetes, histological, histochemical. nary disease in diabetes mellitus was due to the fact that "diabetes enhances the development of arteriosclerosis".

Since then it has been shown that a characteristic and widespread vascular abnormality develops in diabetic patients after many years of disease. This longterm diabetic angiopathy has been studied in many organs, particularly the retinopathy and the nephropathy. It is not clear, however, whether the high incidence of coronary disease in diabetes mellitus should be regarded as the expression of another manifestation of diabetic angiopathy; in other words, whether a diabetic cardiopathy exists. 
That this might be the case is suggested inter alia by the correlation between the incidence of clinical heart disease and retinopathy and vascular abnormalities of the legs (LUNDB AEK, 1953), and also between the incidence of histological kidney disease (biopsy studies) and heart disease in diabetic patients (THomSEN, 1965). Another probably significant point is that the sex-ratio of coronary disease is different in diabetics and non-diabetics. It is well-known that coronary disease in non-diabetics is primarily a man's disease. The incidence of coronary disease in diabetics is about the same in men and women, as is the incidence of retinopathy, nephropathy and also of neuropathy.

KaRLEFors (1966) has recently shown that abnormal exercise electrocardiogram is common in diabetic patients with a long duration of diabetes and with retinopathy.

There are numerous histological studies of diabetic angiopathy in the eyes, the kidneys, the extremities, the gastrointestinal tract etc., but only few studies of the coronary arteries in diabetes mellitus have been published.

The present study was performed to compare the histological and histochemical picture of extramural and intramural coronary arteries in a group of old diabetic patients with a group of old patients without clinical diabetes.

\section{Material}

The investigation included specimens from 20 diabetics and 20 non-diabetics aged 50 to 70 years at the time of death. The age and sex of the patients appear in Table 1, which also gives the average body weight and heart weight in the two groups. The average

\section{Methods}

\section{Autopsy technique}

The hearts were fixed for 1 to 6 months in buffered 4 per cent neutral formaldehyde at room temperature.

Two extramural and one intramural piece of each of the three coronary arteries were removed for examination. The proximal extramural piece was the first centimetre of the artery. The distal one was taken midway between the origin of the artery and the apex cordis. The intramural piece was from the first centimetre of the intramural part of the artery. In addition, two macroscopically normal-looking pieces of myocardium, right and left, were removed for the study of smaller vessels (see Fig. 1).

The kidneys were examined histologically in all cases.

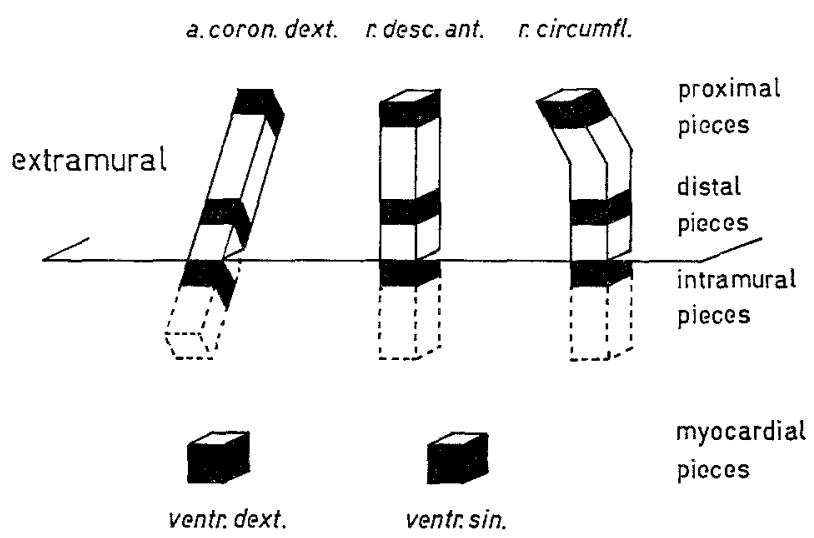

Fig. 1. Sketch of the pieces of coronary arteries and myocardium taken for examination.

Table 1

\begin{tabular}{|c|c|c|c|c|c|c|c|c|}
\hline & \multirow[t]{2}{*}{ Patients } & \multirow[t]{2}{*}{ Men } & \multirow[t]{2}{*}{ Women } & \multicolumn{2}{|c|}{$\begin{array}{c}\text { Average age } \\
\text { (yr) }\end{array}$} & \multirow{2}{*}{$\begin{array}{l}\text { Body } \\
\text { weight } \\
\text { kg }\end{array}$} & \multirow{2}{*}{$\begin{array}{l}\text { Heart } \\
\text { weight } \\
g\end{array}$} & \multirow{2}{*}{$\begin{array}{l}\text { Average known } \\
\text { duration of } \\
\text { diabetes }\end{array}$} \\
\hline & & & & $\overline{\mathrm{M}}$ & $\bar{W}$ & & & \\
\hline \multirow{2}{*}{$\begin{array}{l}\text { Diabetics } \\
\text { Non- } \\
\text { diabetics }\end{array}$} & 20 & 10 & 10 & 62.2 & 66.2 & 68.5 & 482.6 & \multirow[t]{2}{*}{8 years } \\
\hline & 20 & 10 & 10 & 62.5 & 66.3 & 57.4 & 384.5 & \\
\hline
\end{tabular}

known duration of diabetes was 2 to 24 years, with an average of 8 years.

None of the patients had had syphilis or rheumatic fever. The diabetic patients had been suffering from typical, mild maturity-onset diabetes. Non-diabetic patients had not had any symptoms of diabetes mellitus and had not had glucosuria. Glucose tolerance tests were not performed. The non-diabetic patients, selected according to the definition, were found at autopsy not to have diffuse or nodular glomerulosclerosis. The average blood pressure was $160 / 90$ in the group of diabetics, $153 / 88$ in the non-diabetics. In 13 diabetics and 11 non-diabetics the blood pressure was above 150/100. Diabetic nodular glomerulosclerosis was present in 8 of the 20 diabetic patients.

\section{Staining procedures}

Paraffin sections, 4 microns thick, were examined after staining with Hematoxylin-eosin, van GiesonHansen, Orcein (MatLoRY, 1944), PAS, 0.1\% Toluidine blue at $\mathrm{pH} 4.8$ (Pearse, 1960), 1\% Astra blue at $\mathrm{pH}$ 4.1 (BARKA and ANDERSON, 1963) and Chloranilic acid (Ersesstern et al., 1961). For the study of the extramural vessels, $0.1 \%$ Toluidine blue at $\mathrm{pH} 4.8$, was also used after treatment with hyaluronidase, (Penetrase Leo, $50 \mathrm{i}$. u $/ \mathrm{ml}$ at $30^{\circ} \mathrm{C}$ for one hour in Mollvains buffer without gelantine (BERTELSEN, 1964)). Supplementary stainings for the small vessels included PAS after acetylation and after treatment with diastase (PEARSE, 1960), Phosphotungstic acid hematoxylin (PTAH) and WILDER's reticulin stain (MALIORX, 1944). 
Frozen sections ( 6 micron) of the larger arteries were stained with Fettrot (Pearse, 1960).

\section{Estimates and measurements}

All estimates and measurements were made blindly in a coded system.

The observations on extramural vessels were classified as follows.

A. Wall structure. 0: Normal. 1: Less than half of the depth of the intima was loosely structured with small pockets of homogeneous material. 2: Same as 1, but changes were present throughout the tunica intima. Small hyalinized areas were observed as well as foam cells at the luminal side. 3: Broad bands of hyaline with foam cells; fibrosis of the tunica media. 4: Most of the intima was hyalinized or necrotic. Cholesterol crystals or deposits of calcium in the periphery of the intima were often seen.

$B$. Internal elastica membrane. 0: Normal. 1: The entire membrane was present but splitting occurred in some places. 2: Membrane present in more than half of the circumference. 3: Membrane present in less than half of the circumference. 4: Membrane absent.

C. PAS, Toluidine blue and Astra blue. The intensity of the colour was estimated as 0 to 3 plus.

D. Calcium, Fat and Collagen. The extension of the deposits were estimated as 0 to 3 plus.

The statistical estimation of results from the extramural vessels was performed in two ways.

1. From each of the two groups there were 60 proximal extramural pieces, 3 from each of 20 patients, and as many distal ones (see Fig. 1). The percentage incidence of the various grades in these 60 plus 60 proxi. mal or distal pieces was calculated and compared. The significance of the difference between the incidence of each grade in the two groups was estimated by the $\chi^{2}$-test.

2. The average grades of the proximal, and the respective distal pieces of the 3 vessels from each of the 20 plus 20 patients were calculated. These averages were added together, giving a group average for diabetics and one for non-diabeties, which were then compared using the t-test.

The results from the intramural vessels were compared by the $\chi^{2}$-test.

The observations on the intramural vessels (intramural part of coronary artery and small myocardial arteries) were also classified in a semiquantitative system. The intensity of the PAS-staining was estimated as $0-2$ plus. Toluidine blue and Astra blue was estimated as $0-1$ plus. The presence or absence of intimal, medial or adventitial fibrosis as well as medial hypertrophy was also noted.

The thickness of the vascular wall was measured in the smallest vessels (diameter 20-29 micron). Using a magnification of $\times 1080$, one unit on the ocular micrometer equalled 1.3 micron. To avoid too oblique sections, measurements were only performed where the difference between the largest and the smallest dia- meter of the vessel was less than one micrometer unit. From each patient $2-4$ small myocardial vessels fulfilling these requirements were obtained. The wall thickness in the individual case was expressed as the average of two measurements obtained at both ends of the smallest diameter of these vessels. The diameter of the lumen at the point of measurement was noted, and the ratio diameter of lumen/wall thickness, was calculated.

\section{Extramural vessels \\ Results}

Wall structure: In proximal pieces, no difference was seen between diabetics and non-diabetics; in distal pieces, Grade 4 occured more often in diabetics than in non-diabetics $(P<0.05)$. Calculated on the basis of the individual patient the same difference was found $(\mathrm{P}<0.05)$. The structure of the internal elastic membrane, as observed in Orcein stains, was the same in vessels from diabetics and non-diabeties.

Mucopolysaccharides (PAS-positive). In proximal pieces, no difference was seen; in distal pieces, Grade 3 was observed more often in diabetics than in non-diabeties $(\mathrm{P}<0.05)$. Calculated on the basis of the individual patient the same difference was found $(\mathrm{P}<$ $0.05)$.

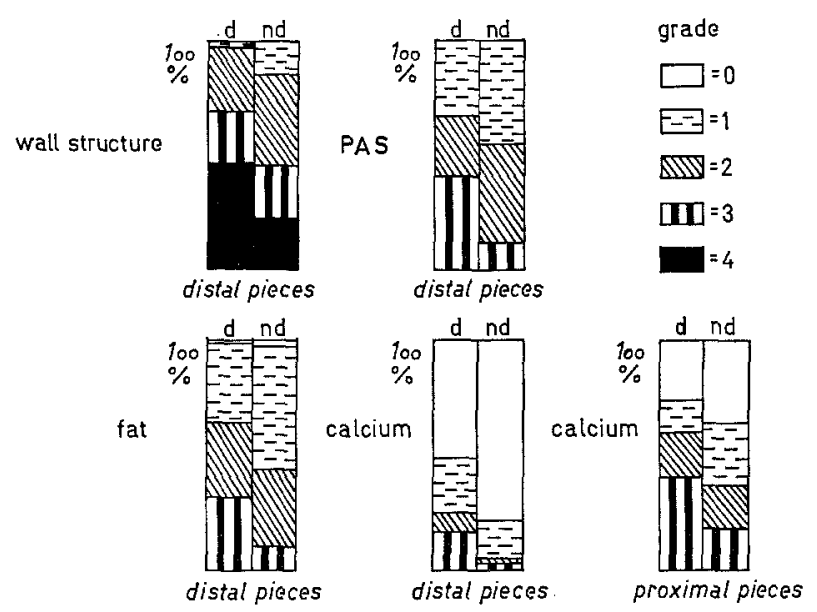

Fig. 2. The incidence of each grade of abnormality in various pieces from diabetics and non-diabetics. $(d=$ diabeties, $n d=$ non-diabetics)

Acid mucopolysaccharides. - Metachromasia (Toluidine blue, with and without hyaluronidase): No differences were observed.

Astra blue: No significant differences were observed.

Fat (F'ettrot stain). In proximal pieces, no difference was seen; in distal pieces, Grade 3 was more commonly seen in diabetics than in non-diabetics $(P<0.05)$. Calculated on the basis of the individual patient the difference is close to the limit of significance $(t=$ $1.956, t_{0 \cdot 05}$ for $\left.P<0.05=2.02\right)$.

Calcium (Chloranilic acid). In proximal pieces, Grade 3 was more commonly seen in diabetics than in non-diabetics $(P<0.05)$. Calculated on the basis of 
the individual patient the difference is close to the limit of significance $\left(t=1.947, t_{0.05}\right.$ for $P<0.05=$ 2.02).
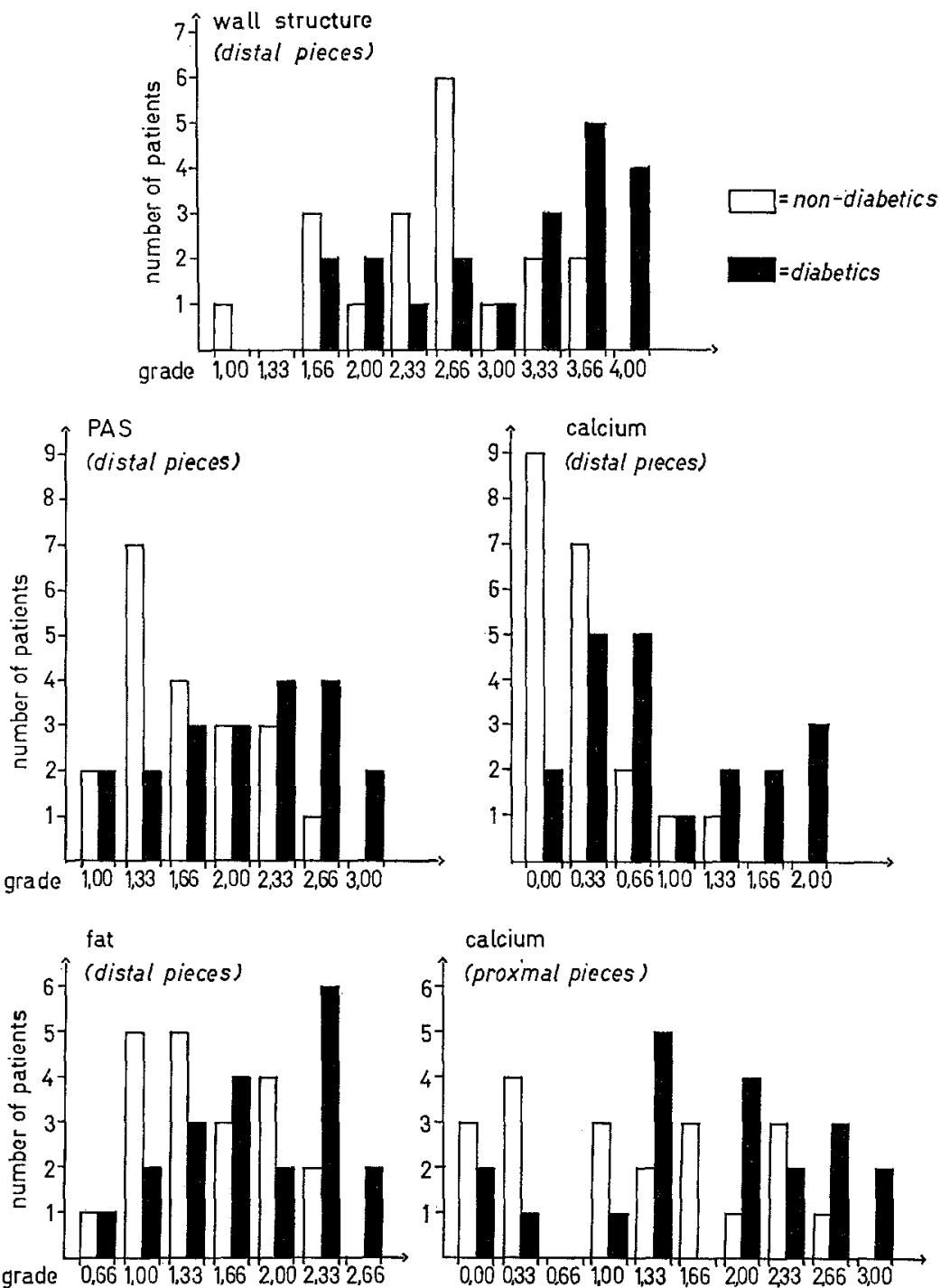

calcium

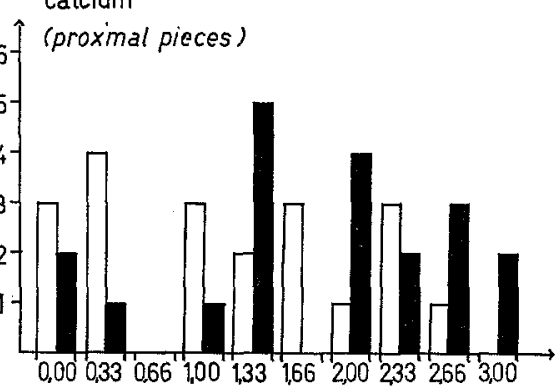

Fig. 3. Number of patients showing various average grades of abnormality
No difference was noted in the amount of collagen (vaN GIESon-HANSEN) between diabetics and nondiabetics.

Fig. 2 and 3 show the distributions in the cases where significant differences were observed.

Intramural vessels

Table 2 shows the results of the estimates from intramural vessels (intramural pieces of coronary arteries and smaller arteries of the myocardium). The vessels have been divided in 4 intervals of luminal width.

The only striking result was a higher incidence of Garde 2 in the small vessels $(20-70$ and $70-150 \mu)$ from diabetic patients $(P<0.05)$. The PAS-positive substance of the Grade 2 vessels was usually arranged in concentric rings, only a few instances of PAS-positive drops being observed. The substance did not react to staining for acid mucopolysaccharides, glycogen, collagen, fibrin (PTAH) or reticulin.

ation in the small vessels showing

There was no endothelial proliferaccumulation of PAS-positive substance.

There was no correlation between the occurrence of PAS-positive substance (Grade 2) in small arteries and the blood pressure. However, the occurrence of PAS-positive (Grade 2) small vessels of the myocardium was closely related to the occurrence of nodular glomerulosclerosis in the kidney sections. All the eight cases with nodular glomerulosclerosis fell in the group with PAS-positive small vessels (Grade 2) in the heart.

Table 2. Number of diabetics (out of 20) and non-diabetics (out of 20) showing small vessel abnormality according to the definition (see the text). $D=$ diabetics, $N D=$ non-diabetics

\begin{tabular}{|c|c|c|c|c|c|c|c|c|}
\hline \multirow[t]{2}{*}{ Dimater of the vessels $(\mu)$} & \multicolumn{2}{|c|}{$20-60$} & \multicolumn{2}{|c|}{$70-150$} & \multicolumn{2}{|c|}{$150-500$} & \multicolumn{2}{|c|}{500} \\
\hline & $\mathrm{D}$ & $\mathrm{ND}$ & $\mathrm{D}$ & $\mathrm{ND}$ & $\mathrm{D}$ & ND & $\mathrm{D}$ & ND \\
\hline PAS-positive (grade 2) & 15 & 7 & 12 & 5 & 3 & 0 & 14 & 14 \\
\hline Toluidine blue (grade 1) & 0 & 1 & 2 & 2 & 7 & 7 & 10 & 15 \\
\hline Astra blue (grado 1) & 1 & 1 & $\overline{1}$ & 1 & 10 & 7 & 14 & 17 \\
\hline Intimal fibrosis & $1 \tilde{4}$ & 18 & 19 & 16 & 19 & 18 & 16 & 18 \\
\hline Medial fibrosis & 17 & 15 & 20 & 18 & 20 & 17 & 16 & 18 \\
\hline Medial hypertrophy & 8 & 2 & 7 & 5 & 4 & 1 & & \\
\hline Adventitial fibrosis & 10 & 12 & 15 & 14 & $1 \overline{7}$ & 10 & 16 & 15 \\
\hline
\end{tabular}

In distal pieces, Grade 3 and 2 were more commonly seen in diabetics than in non-diabetics $(P<0.05)$. Calculated on the basis of the individual patient the same difference was found $(P<0.05)$.
Wall thickness. There was no statistically significant difference between diabetics and non-diabetics as regards the thickness of the vascular wall in the smallest vessels (20-29 micron). Diameter of lumen/wall thick- 
ness was the same in diabetics and non-diabetics, viz. 0.28 and 0.25 .

\section{Discussion}

The two series selected for comparison were closely similar as to average age in the two sex groups. The diabetics were heavier, as was to be expected, and the heart weight was higher. The average blood-pressure was nearly identical in the two groups.

The extramural vessels of diabetics and nondiabetics differed in structure and certain histochemical aspects. Abnormal structure with severe hyalinization was seen more often in diabetics than in non-diabetics. The diabetic arteries were more PAS-positive and contained more fat than the nondiabetic ones. These differences have been demonstrated only in the distal part of the extramural coronary vessels. The diabetic arteries were more calcified than the non-diabetic ones, proximally as well as distally. These results differ from those of Root (1928).

In a study of the arteriosclerotic aorta BERTELSEN (1964) has shown that there is a positive correlation between the deposition of PAS-positive and metachromatic material. In our study, although metachromasia was present it was not more intense in the distal vessels of the diabetic patients which showed strong PAS-positivity.

The study of intramural vessels revealed differences only in the smallest arteries. These vessels showed concentric rings of PAS-positive material much more often in the diabetics than in the nondiabetics. This finding is in accordance with that of BLUMENTHAL et al., (1960) and a tendency in the same direction was observed by NIIELSEN (1965). Our histochemical studies have shown that the PAS-positive material is not glycogen, collagen, fibrin or reticulin and there is stet no acid mucopolysaccharide. The presence of acid mucopolysaccharide in small intramural vessels of diabetics was reported by Crcala and MariN (1960) from a small series of patients. Our findings were negative in this respect, as was that of BLUMENTHAL et al. (1960).

The deposits of PAS-positive material in the smallest intramural branches of the coronary arteries do not result in a measurable thickening of the vascular wall.

BLUMENTHAL et al, $(1960,1961,1962)$ and GoLdENBERG et al. (1959) emphasized endothelial proliferation of small blood vessels in various organs as the most conspicious diabetic characteristic (heart, eyes, kidneys and extremities). PeDkrsen and Otsen (1962) found endothelial proliferation in the small arteries in muscle and skin biopsies from the legs in 5 out of 16 diabetics, but also observed this lesion in non-diabetics. Endothelial profilferation was not present in the renal vessels in the study of THomsen (1965). In the present study of coronary vessels such changes have not been observed.

The overall result of the present study points to a difference between the histological picture of the coro- nary arteries in old diabetics and that in nondiabetic patients.

The changes commonly observed in the smallest intramural branches in the diabetic patients are quite similar to those observed in other organs in long-term diabetes. Although our series are small, the findings presented lend some support to the hypothesis of a diabetic cardiopathy.

\section{References}

Barka, T. and P.J. Anderson: Histochemistry. Theory, practice and bibliography. New York: Harper \& Row 1963.

Bertelsen, S.: Atherosclerose og aldersforandringer $\mathrm{i}$ humane arterier af elastisk type. København: Munksgaard 1964

- Personal communication to the auther, 1964.

BLUMrenthat, H.T., M. ALEX, and S. GoldenBerg: A study of lesions of the intramural coronary artery branches in diabetes mellitus. Arch. Path. 70, 13-28 1960 .

- A.W. Berns, C.T. Owens, and Y. Hrrata: The pathogenesis of diabetic glomerulosclerosis. Diabetes 11, 296-307 (1962).

- M. Alex, and S. Goldenberg: A non-atheromatous proliferative vascular lesion of the retina in diabetes mellitus. Amer. J. Med. 31, 382-396 (1961).

Crcala, V., and A. Marin: Ricerche istologische ed istochimische sulla coronaropatia diabetica e arteriosclerotica. Riv. Anat. pat. Oncol. 18, 755-786 (1960).

Clawson, B.J., and E.T. BELL: Incidence of fatal coronary disease in non-diabetic and in diabetic persons. Arch. Path. 48, 105-107 (1949).

Etsenstein, R. M. Werner, S. Papjiannis, W. Konerz$\mathrm{KI}$, and I. LATNG: Chloranilic acid as a histochemical reagent for calcium. J. Histochem. Cytochem. 9, $154-156$ (1961).

Goldenber, S., M. Alfx, R.A. Joshi, and H.'T. BlumenTHAr: Non-atheromatous peripheral vascular disease of the lower extremity in diabetes mellitus. Diabetes $\mathbf{8}$, $261-273(1959)$.

Kartefors, T.: Circulatory studies in male diabetics. Halmstad 1966.

Linbow, I.M., H.K. HedLerstein, and M. MiLter: Arteriosclerotic heart disease in diabetes mellitus. Amer. J. Med. 18, 438-447 (1955).

LUNDBдек, K.: Long-term diabetes. Copenhagen: Ejnar Munksgård 1953.

MaLLony, F.M.: Pathological technique. Philadelphia: Saunders Company 1944.

NIELser, E. : Cardiopathia diabetica? A prize paper submitted to the University of Åarhus 1965.

- Coronarsygdom ved diabetes mellitus. Acta Jutl. 1967, XXXIX 1.

Pearse, A.G.P.: Histochemistry. Theoritical and applied. London: Churchill 1960.

Pedersen, J., and T.S. Olsen: Small-vessel disease of the lower extremity in diabetes mellitus. Acta med. scand. 171, 551-559 (1962).

Root, H.F.: Arteriosclerosis in the legs and heart in diabetes. N.Y. St. J. Med. 28, 1287-1290 (1928).

Thomesen, A.C.: The kidney in diabetes mellitus. Copenhagen: Munksgård 1965.

Thomas Lemet, M. D.

The University Institute of Pathology

and the 2nd University Clinic of Internal

Medicine

Kommunehospitalet

Aarhus, Denmark 